\title{
Evaluation of the Use of Cloud Storage on Academic Website Using SWOT Analysis and Balanced Score Card
}

\author{
Eri Rustamaji \\ State Islamic University Syarif \\ Hidayatullah Jakarta, Indonesia \\ eri.rustamaji@uinjkt.ac.id. \\ Viranda Adhiazni \\ State Islamic University Syarif \\ HidayatullahJakarta, Indonesia \\ viranda.adhiazni16@mhs.uinjkt.ac.id \\ Firna Helfira \\ State Islamic University Syarif \\ Hidayatullah \\ Jakarta, Indonesia \\ Firna.helfira16@mhs.uinjkt.ac.id
}

\author{
Aprilia Dian \\ State Islamic University Syarif \\ Hidayatullah \\ Jakarta, Indonesia \\ Aprilia.dian16@mhs.uinjkt.ac.id \\ Tesa Jamilatul Qomariah \\ State Islamic University Syarif \\ Hidayatullah \\ Jakarta, Indonesia \\ tesa.jamilatul16@mhs.uinjkt.ac.id \\ Fandi Setiadi \\ State Islamic University Syarif \\ Hidayatullah Jakarta, Indonesia
}

\author{
fandi.setiadi16@mhs.uinjkt.ac.id \\ Sutian Zaenal \\ State Islamic University Syarif \\ Hidayatullah \\ Jakarta, Indonesia \\ sutian.zaenal15@mhs.uinjkt.ac.id \\ Nurbojatmiko \\ State Islamic University Syarif \\ Hidayatullah \\ Jakarta, Indonesia \\ Nurbojatmiko@uinjkt.ac.id
}

\begin{abstract}
Data security and data leakage is an important issue in a dangerous technology in Cloud Storage systems on Cloud Computing. Academic website also faced problems like data leakage and system hacked for certain purposes. To achieve an appropriate level of data security standard on the Cloud Storage for academic website, the strengths and weaknesses in data security of Cloud Storage on academic website was evaluated using SWOT analysis. The analysis is based on four layers that exist in the cloud storage structure, namely access Cloud Storage. This is important since in recent years, many incident took place on attacks layer, application layer interfaces, management layer, and storage layer. The study also evaluates the performance of cloud storage by measuring the academic website using IT Balanced Scorecard which based on four perspectives of IT Balanced Scorecard. This study focuses only on Cloud Storage website of Academic Information System (AIS) UIN Jakarta, since many hacking incident on student accounts while there is no evaluation results on the website AIS Cloud usage.
\end{abstract}

Keywords: Cloud Computing, Cloud Storage, data security

\section{INTRODUCTION}

Cloud storage technology makes full use of the existing different storage devices in the system to provide users with data storage, data retrieval, data backup and other functions through application software ran by a user terminal. In recent years, attacks and data leakage in cloud storage system within Cloud Computing seemed to be increased [1].

In previous research,[1], use risk analysis to the 4 layers in Cloud Storage technology. The result showed that the technology developed very fast, and cloud storage security technology is facing unprecedented challenge. However, cloud storage security is not just a technical issue. It also involves standardization, management, laws and regulations and other problems. [2], analyze safety hazards of Cloud Computing. In this analysis discussed traditional and approved security solutions and procedure evaluation parameters. It was discussed also the procedure for evaluating parameter are determined. Those will be provided as one packaged solution. [3] get the result that in multi-layer cloud network, any device can augment its resources by taking off his duties to the public cloud, private cloud, or even the user's device. However, it is difficult to handle access control on data stored in different clouds that offer variety of access control.

This research is focused on the cloud storage system UIN Jakarta Academic Information System (AIS) website. We evaluated it by using SWOT analysis approach and methods of IT Balanced Scorecard as performance measurement on the application of information technology. This research focuses on strategic objectives of the academic website with measurement dimensions variable adapted to the academic website

\section{LITERATURE STUDY}

\section{A. Cloud Storage}

Cloud Storage operates through a Web-based API that is implemented remotely through interaction with the infrastructure of in-house cloud storage client applications for input / output (I / O) and read / write operations (R / W) [4]. Standard Cloud Storage can help to overcome the problems of accessibility, security and portability issues and the costs associated with growing data sets [5].

The advantage of Cloud Storage in the academic field are to minimize investment costs in academic 
infrastructure, to enable the development and implementation of applications quickly that is increasing productivity in the academic field, and to facilitate the integration of the academic system services with various devices [5].

\section{B. Four Layer Cloud Storage}

The structure of cloud storage system consists of four layers:

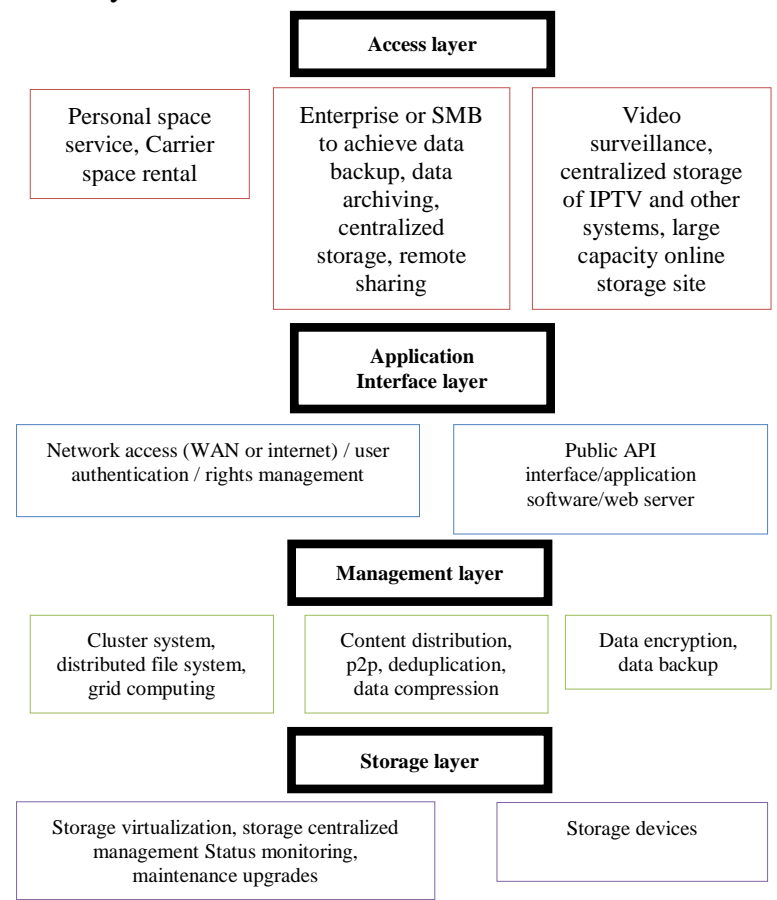

Figure 1. Layer in Cloud Storage [1].

\section{- Storage layer}

Storage layer is the most basic part of cloud storage. The storage device can be in Fiber Channel FC storage devices. This could also be an IP storage device such as NAS and iSCSI, or direct-attached storage (DAS) devices such as SCSI or SAS.

- Management layer

Management layer implements collaboration between multiple storage devices in cloud storage through clusters, distributed file systems, and grid computing technology. This enable multiple storage devices provide the same services and to have bigger and better data access performance.

- Application interface layer

Application interface layer is the most flexible part of cloud storage. In the actual type of business, different cloud storage operators can develop a different application service interface, and providing a wide range of services.

\section{- Access layer}

Each authorized user can access the cloud storage system through a standard public application interface and enjoy the cloud storage service. The types and methods of access provided by cloud storage are the results from different operating unit.

\section{IT Balanced Scored Card}

Balanced Score Card (BSC) is the effective tools of performance management. It uses measurable indicators for assessing organization's implementation and strategic targets [6]. The BSC develops the four views index. They are learning and growth, internal processes, customers, and finances. BSC goal is balancing the financial target as a result of past performance, and three other indices (future display index) [7].

Table1. Four Perspectives of IT BSC [7]

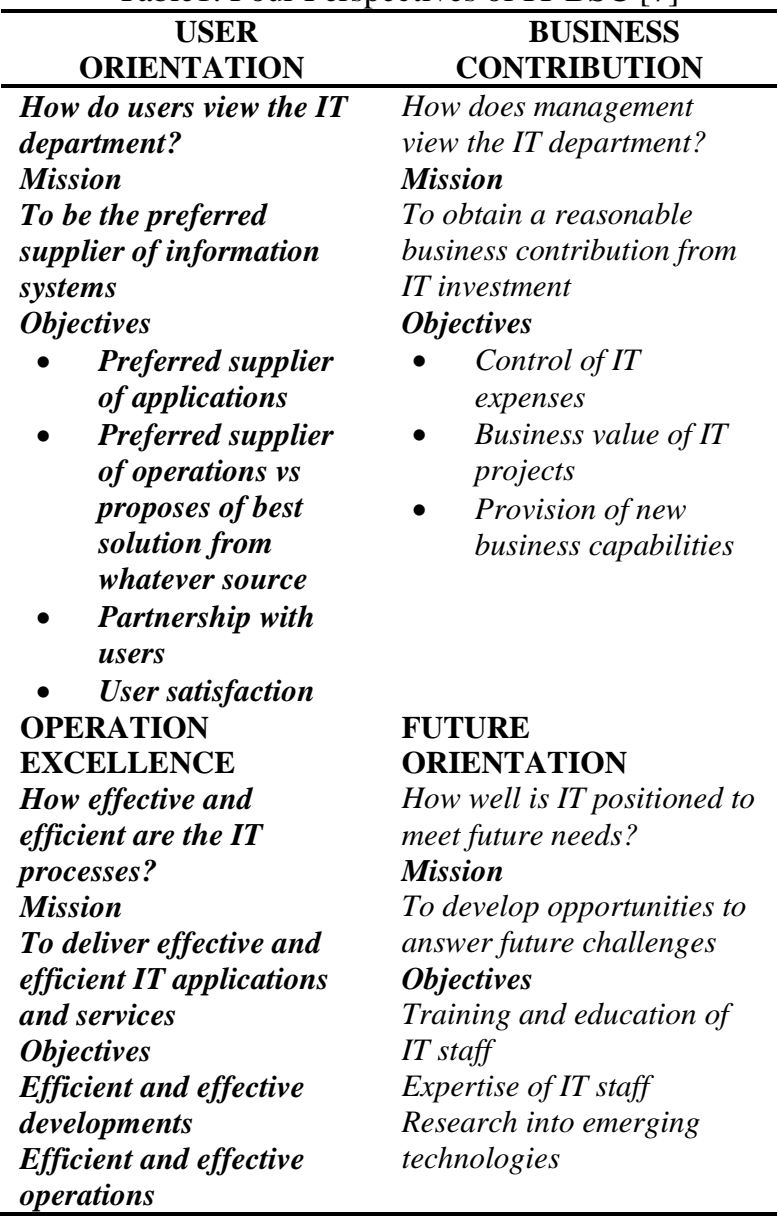

IT Balanced Scorecard: the outcome of measures and performance drivers [8]. IT Balanced Scorecard to provide a comprehensive and structured presentation and review. It will allow related managers to monitor the strategy of IT implementation based on the value of each IT perspective [9].

\section{SWOT Analysis}

SWOT is an abbreviation for Strength (Strength), Weakness (Weakness), Opportunity (Opportunity), and Threat (Threat) which is a strategic factor specific to a particular company [10] 


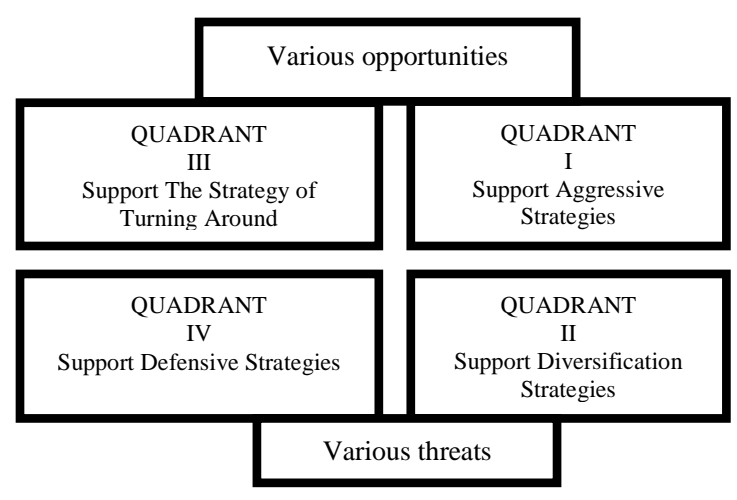

Figure 2. SWOT Diagram [11]

SWOT analysis is used to determine the position currently experienced by the company, and to determine the strategic directions can be taken by company using a SWOT Analysis Diagram. SWOT can also be used to produce a number of possible alternative strategies. The TOWS matrix (TOWS is just another way of saying SWOT) describes how the external opportunities and threats faced by a particular company can be matched with the company's internal strengths and weaknesses that can produce four possible alternative sets of strategies.

\begin{tabular}{|c|c|c|}
\hline $\begin{array}{l}\text { INTERNAL } \\
\text { FACTORS } \\
\text { (IFAS) }\end{array}$ & $\begin{array}{l}\text { Strengths (S) } \\
\text { List 5-10 internal } \\
\text { strengths here }\end{array}$ & $\begin{array}{l}\text { Weaknesses }(W) \\
\text { List 5-10 internal } \\
\text { weaknesses here }\end{array}$ \\
\hline $\begin{array}{l}\text { EXTERNAL } \\
\text { FACTORS } \\
\text { (EFAS) } \\
\end{array}$ & & \\
\hline $\begin{array}{l}\text { Opportunities }(O) \\
\text { List } 5-10 \text { external } \\
\text { opportunities here }\end{array}$ & $\begin{array}{l}\text { SO Strategies } \\
\text { Generate strategies } \\
\text { here that use } \\
\text { strengths to take } \\
\text { advantage } \\
\text { opportunities }\end{array}$ & \begin{tabular}{l}
\multicolumn{3}{l}{ SO Strategies } \\
Generate strategies \\
here that take \\
advantage \\
opportunities by \\
overcoming \\
weaknesses
\end{tabular} \\
\hline $\begin{array}{l}\text { Threats }(\mathrm{T}) \\
\text { List } 5-10 \text { external } \\
\text { threats here }\end{array}$ & $\begin{array}{l}\text { ST Strategies } \\
\text { Generate strategies } \\
\text { here that use } \\
\text { strengths to avoid } \\
\text { threats }\end{array}$ & $\begin{array}{l}\text { WT Strategies } \\
\text { Generate strategies } \\
\text { here that minimize } \\
\text { weaknesses and } \\
\text { avoid threats }\end{array}$ \\
\hline
\end{tabular}

\section{E. Academic Information System}

Academic information is very important information for students. Some academic information has a certain deadline, therefore, it must be delivered to the student as soon as possible[13]. Web Services technology offers convenience of bridging information resources no matter what technology used by each source [14]. Academic information systems can clarify the academic path of students during their studies and increasing integrity and transparency by providing equal information to all stakeholders. This also adds convenience by allowing access from anywhere through web [15]. In the Academic Web, electronic resources from this organization are very informative and can be used as sources of new media for science and contribute to promote scientific knowledge [16].

\section{METHOD}

Method used in this study can be explained as follows:

1) LiteratureStudy

At this stage, the study was done on literature related to cloud storage, risk analysis, performance measurement, Balanced Scorecard and IT Balanced Scorecard. From the literature, it is expected to learn the description of risk analysis in the cloud storage and performance measurement of academic website using IT Balanced Scorecard

\section{2) Data collection}

Methods used for data collection was interview. Interview was conducted to the Pustipanda UIN Jakarta. The interviews is about cloud storage, cloud storage risks on the web academic, advantages and disadvantages of cloud storage academic web and how to cope if the risk occurs in the cloud storage academic web.

3) Data processing

The result of interviews with Pustipanda was compared to IT perspective Balanced Scorecard. The result constitute the basis for formulating key performance indicator (KPI) of cloud storage academic website. Then create SWOT matrix to learn the internal strengths and weaknesses of cloud storage academic website. The KPI and target that was set are mapped into four perspective of IT BSC which are contributions from organizations, user orientation, operational improvement, and future contributions.

Later each KPI was measured. Actual condition value is obtained from the following calculation: each answer on scale 1-5 is multiplied by its weight. Each result for all answer is added up. Then the total value is divided by the number of respondents. Then the total value multiplied by $20 \%$ ( $20 \%$ because of the scale there are 5, then $100 \%$ : 5). To calculate the weighted results using the formulation of strategic objectives as follows: 1 ) weight $=$ weight value comes from the academic website management, 2) the result of interest $=($ result size $/ 100) \mathrm{x}$ weight, 3$)$ the results of the average size $=$ result of achievement of data processing from each perspective of IT Balanced Scorecard, 4) total is the percentage of each perspective.

- Data analysis and determination of the level of performance

The measurement results are then analyzed so it can be determined which aspects are less supportive to the achievement of the strategic plan so that corrective action can be taken. Its 
measurement results is in the form of scorecard that contains values to each IT perspective BSC which will determine the level of academic web performance.

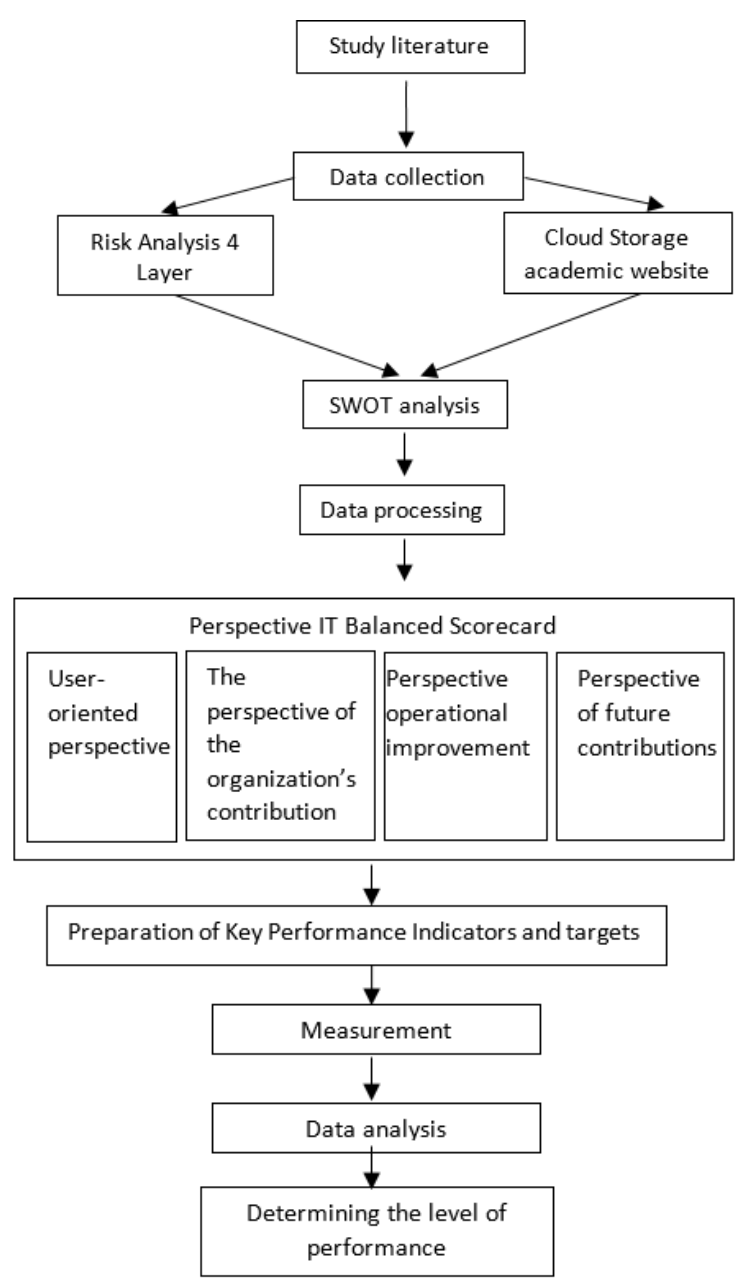

Figure 3. Research Method

\section{RESULTS AND DISCUSSION}

The information system object for the research is a web-based academic information system. The function of this system is to provide data sources and academic administration that covers institution data, student data, lecturers'data, scholarship data, lecture scheduling, academic transcripts, study plan cards, study results cards, summary data, and academic transaction report for students.

Security on the academic system is good enough because the system utilize Secure Storage Layer (SSL), encrypting visitors so that it is difficult to be hacked. Programming language uses the Java language, the Linux operating system and the Tomcat service. Some anticipation if there hacked data, namely by using SSL, separating the database server, application server and streaming database server.

\section{A. SWOT Analysis 4 Layers Cloud Storage}

Cloud storage for academic website has an advantage to be accessed from anywhere.

There are some network factors need to be considered, namely 1) problem compilation related to connection of internet service provider (ISP), 2) user accessing the academic systems is increasing, 3) storage space crash the systems. Cloud storage in academic systems contain four layers. Namely, storage layer, management layer, application layer, and interface of access layer. The following is SWOT analysis for academic systems of four layers cloud storage.

Table 3. SWOT Matrix Academic Cloud Storage System

\begin{tabular}{|c|c|c|c|}
\hline $\begin{array}{l}\text { Strengths } \\
\text { (S) } \\
\text {-Cloud } \\
\text { Academic } \\
\text { System } \\
\text { Storage can } \\
\text { be accessed } \\
\text { anywhere, } \\
\text {-Backup } \\
\text { Data }\end{array}$ & $\begin{array}{l}\text { Weakness } \\
\text { (W) } \\
\text {-Can occur } \\
\text { hang when } \\
\text { visiting } \\
\text { crowded and } \\
\text { space is full } \\
\text { of } \\
\text { uncontrolled } \\
\text { storage. }\end{array}$ & $\begin{array}{l}\text { Opportunity } \\
\text { (O) } \\
\text {-Rejuvenation } \\
\text { device } \\
\text {-mirroring } \\
\text { and routines } \\
\text { perform data } \\
\text { backup } \\
\text { internet } \\
\text { bandwidth }\end{array}$ & $\begin{array}{l}\text { Threats (T) } \\
\text {-Server } \\
\text { down can } \\
\text { occur if a } \\
\text { visit to the } \\
\text { bustling } \\
\text { academic } \\
\text { system }\end{array}$ \\
\hline SO & ST & WO & WT \\
\hline $\begin{array}{l}\text { Already } \\
\text { using SSL } \\
\text { in } \\
\text { anticipation }\end{array}$ & $\begin{array}{l}\text {-Using the } \\
\text { SSL } \\
\text {-Separate } \\
\text { database } \\
\text { server, } \\
\text { application, } \\
\text { streaming } \\
\text { database } \\
\text {-Network } \\
\text { aspect: install } \\
\text { a firewall }\end{array}$ & $\begin{array}{l}\text {-create } \\
\text { multiple } \\
\text { virtual } \\
\text { storage space }\end{array}$ & $\begin{array}{l}\text { using java } \\
\text { in operation }\end{array}$ \\
\hline
\end{tabular}

\section{B. Data processing}

The composition of KPI was started by studying the perspective of IT BSC. The perspective was aligned with strategic goal of academic information systems so that the KPI for academic information systems is displayed in Table 4.

Table 4. Key Performance Indicator

\begin{tabular}{|c|c|}
\hline BSC IT Perspective & $\begin{array}{c}\text { Key Performance } \\
\text { Indicator }\end{array}$ \\
\hline \multicolumn{2}{|c|}{ Contributions Organization } \\
\hline $\begin{array}{l}\text { Achieve organizational } \\
\text { contribution that is the business } \\
\text { value of information technology } \\
\text { and the effectiveness from the } \\
\text { application information systems }\end{array}$ & $\begin{array}{l}\text { Improving the } \\
\text { effectiveness of } \\
\text { academic administrative } \\
\text { services }\end{array}$ \\
\hline \multicolumn{2}{|l|}{ User Orientation } \\
\hline $\begin{array}{l}\text { Providing information systems } \\
\text { on-demand to achieve user } \\
\text { satisfaction }\end{array}$ & $\begin{array}{l}\text {-Operator system of } \\
\text { satisfaction } \\
\text {-Increase the system } \\
\text { operator competency }\end{array}$ \\
\hline \multicolumn{2}{|l|}{ Operational Improvement } \\
\hline $\begin{array}{l}\text { Providing maximum IT products } \\
\text { and services for effective and } \\
\text { efficient information systems }\end{array}$ & $\begin{array}{l}\text { Improving the quality of } \\
\text { information systems }\end{array}$ \\
\hline \multicolumn{2}{|l|}{ Future Orientation } \\
\hline $\begin{array}{l}\text { Answering the challenges of the } \\
\text { future by educating and training } \\
\text { the IT staff as well a research on } \\
\text { the development of IT }\end{array}$ & $\begin{array}{l}\text { Increase IT staff } \\
\text { expertise }\end{array}$ \\
\hline
\end{tabular}


Total of 15 questionnaires were sent out, and

Then for the KPI that had been set, targets are determined specifically for each KPI. KPIs and targets were reassembled into their respective IT perspective Balanced Scorecard as shown in Table 5

KPI targets derived from the translation of each IT Balanced Scorecard perspective so that it comes into several sizes. Next step is determining the final value of the balanced scorecard prior to calculation of IT balanced score card.

Table 5. Target KPI

\begin{tabular}{|l|l|l|}
\hline \multicolumn{1}{|c|}{$\begin{array}{c}\text { BSC IT } \\
\text { Perspective }\end{array}$} & KPI & Target (\%) \\
\hline $\begin{array}{l}\text { Contributions } \\
\text { Organization }\end{array}$ & $\begin{array}{l}\text { Improving the } \\
\text { effectiveness of } \\
\text { academic } \\
\text { administrative services }\end{array}$ & 80 \\
\hline User Orientation & $\begin{array}{l}\text {-Operator system of } \\
\text { satisfaction }\end{array}$ & 75 \\
\cline { 2 - 3 } & $\begin{array}{l}\text {-increase the system } \\
\text { operator competency }\end{array}$ & 80 \\
\hline $\begin{array}{l}\text { Operational } \\
\text { Improvement }\end{array}$ & $\begin{array}{l}\text { System Quality } \\
\text { Improvement }\end{array}$ & 78 \\
\hline Future Orientation & $\begin{array}{l}\text { Increase IT staff } \\
\text { expertise }\end{array}$ & 75 \\
\hline
\end{tabular}

Table 6. Value End Performance Balanced Scorecard

\begin{tabular}{|l|l|l|}
\hline $\begin{array}{l}\text { Value } \\
\text { (Score)\% }\end{array}$ & Scale & Category \\
\hline $73-85$ & 5 & Excellent \\
\hline $59-72$ & 4 & Best \\
\hline $45-58$ & 3 & Good \\
\hline $31-44$ & 2 & Bad \\
\hline $17-30$ & 1 & Very Bad \\
\hline
\end{tabular}

Table 7. Results of Data Processing Perspective User Orientation

\begin{tabular}{|c|c|c|c|c|}
\hline $\begin{array}{l}\text { Strategic } \\
\text { Goals }\end{array}$ & Strategic size & $\begin{array}{c}\text { Stra } \\
\text { tegic } \\
\text { targ } \\
\text { et }\end{array}$ & $\begin{array}{c}\text { Actual } \\
\text { conditi } \\
\text { ons }\end{array}$ & $\begin{array}{l}\text { Achiev } \\
\text { ement }\end{array}$ \\
\hline \multirow{10}{*}{$\begin{array}{l}\text { Providing } \\
\text { informatio } \\
\mathrm{n} \text { systems } \\
\text { on-demand } \\
\text { to achieve } \\
\text { user } \\
\text { satisfactio } \\
\mathrm{n}\end{array}$} & $\begin{array}{l}\text { BANK Officer } \\
\text { appearance }\end{array}$ & $75 \%$ & $73 \%$ & $74 \%$ \\
\hline & $\begin{array}{l}\text { Officer control in } \\
\text { matters }\end{array}$ & $80 \%$ & $68 \%$ & $74 \%$ \\
\hline & $\begin{array}{l}\text { Speed of response } \\
\text { officers }\end{array}$ & $80 \%$ & $67 \%$ & $74 \%$ \\
\hline & $\begin{array}{l}\text { seriousness and } \\
\text { patience officer }\end{array}$ & $80 \%$ & $67 \%$ & $74 \%$ \\
\hline & alacrity of officer & $80 \%$ & $68 \%$ & $74 \%$ \\
\hline & $\begin{array}{l}\text { Officers timely } \\
\text { solve problems. }\end{array}$ & $75 \%$ & $60 \%$ & $68 \%$ \\
\hline & $\begin{array}{l}\text { The credibility of } \\
\text { the officer. }\end{array}$ & $75 \%$ & $71 \%$ & $73 \%$ \\
\hline & $\begin{array}{l}\text { Hear any } \\
\text { complaints } \\
\text { properly. }\end{array}$ & $75 \%$ & $68 \%$ & $72 \%$ \\
\hline & $\begin{array}{l}\text { Friendly and } \\
\text { courteous attitude } \\
\text { of the officers. }\end{array}$ & $75 \%$ & $75 \%$ & $75 \%$ \\
\hline & $\begin{array}{l}\text { An understanding } \\
\text { of the user's } \\
\text { problem. }\end{array}$ & $75 \%$ & $69 \%$ & $75 \%$ \\
\hline \multicolumn{4}{|l|}{ Total } & $731 \%$ \\
\hline \multicolumn{4}{|l|}{ Average } & $73 \%$ \\
\hline
\end{tabular}
returned as much as 15 questionnaires, a total of 15 questionnaires were answered. Table $7 \mathrm{~s} / \mathrm{d}$ Table 10 is a recapitulation of the calculation data processing for each IT perspective Balanced Scorecard.

Table 8. Results of Data Processing Perspective Contributions Organization

\begin{tabular}{|c|c|c|c|c|}
\hline $\begin{array}{l}\text { Strategic } \\
\text { Goals }\end{array}$ & $\begin{array}{l}\text { Strategic } \\
\text { size }\end{array}$ & $\begin{array}{c}\text { Strategic } \\
\text { target }\end{array}$ & $\begin{array}{c}\text { Actual } \\
\text { conditi } \\
\text { ons }\end{array}$ & $\begin{array}{l}\text { Achiev } \\
\text { ement }\end{array}$ \\
\hline \multirow{4}{*}{$\begin{array}{l}\text { Achieve } \\
\text { organizational } \\
\text { contribution } \\
\text { that is the } \\
\text { business value } \\
\text { of information } \\
\text { technology } \\
\text { and the } \\
\text { effectiveness } \\
\text { from the } \\
\text { application } \\
\text { information } \\
\text { systems }\end{array}$} & $\begin{array}{l}\text { The } \\
\text { procedure } \\
\text { for } \\
\text { applying } \\
\text { clear }\end{array}$ & $80 \%$ & $72 \%$ & $76 \%$ \\
\hline & $\begin{array}{l}\text { Supplies } \\
\text { adequate } \\
\text { physical }\end{array}$ & $80 \%$ & $75 \%$ & $78 \%$ \\
\hline & $\begin{array}{l}\text { Services } \\
\text { via } \\
\text { telephone. }\end{array}$ & $80 \%$ & $57 \%$ & $69 \%$ \\
\hline & $\begin{array}{l}\text { Certainty of } \\
\text { time. }\end{array}$ & $80 \%$ & $57 \%$ & $69 \%$ \\
\hline \multicolumn{4}{|l|}{ Total } & $291 \%$ \\
\hline \multicolumn{4}{|l|}{ Average } & $73 \%$ \\
\hline
\end{tabular}

Table 9. Results of Data Processing Perspective Operational Excellence

\begin{tabular}{|c|c|c|c|c|}
\hline $\begin{array}{c}\text { Strategic } \\
\text { Goals }\end{array}$ & $\begin{array}{l}\text { Strategic } \\
\text { size }\end{array}$ & $\begin{array}{c}\text { Strategic } \\
\text { target }\end{array}$ & $\begin{array}{c}\text { Actual } \\
\text { conditi } \\
\text { ons }\end{array}$ & $\begin{array}{l}\text { Achiev } \\
\text { ement }\end{array}$ \\
\hline \multirow{5}{*}{$\begin{array}{l}\text { Providing } \\
\text { maximum IT } \\
\text { products and } \\
\text { services for } \\
\text { effective and } \\
\text { efficient } \\
\text { information } \\
\text { systems }\end{array}$} & $\begin{array}{l}\text { Easy } \\
\text { operation } \\
\text { and to } \\
\text { facilitate } \\
\text { student } \\
\text { activities and } \\
\text { lectures. }\end{array}$ & $78 \%$ & $83 \%$ & $81 \%$ \\
\hline & $\begin{array}{l}\text { Easily } \\
\text { accessible } \\
\text { anywhere } \\
\text { and anytime. }\end{array}$ & $78 \%$ & $79 \%$ & $79 \%$ \\
\hline & $\begin{array}{l}\text { Fast access } \\
\text { and fast } \\
\text { download } \\
\text { process. }\end{array}$ & $78 \%$ & $67 \%$ & $73 \%$ \\
\hline & $\begin{array}{l}\text { Network is } \\
\text { not easy } \\
\text { down. }\end{array}$ & $78 \%$ & $45 \%$ & $62 \%$ \\
\hline & $\begin{array}{l}\text { Data } \\
\text { confidentialit } \\
\text { y secured } \\
\text { and not } \\
\text { easily } \\
\text { hacked. }\end{array}$ & $78 \%$ & $61 \%$ & $70 \%$ \\
\hline \multicolumn{4}{|l|}{ Total } & $363 \%$ \\
\hline \multicolumn{4}{|l|}{ Average } & $73 \%$ \\
\hline
\end{tabular}


Table 10. Results of Data Processing Perspective Future Orientation

\begin{tabular}{|c|c|c|c|c|}
\hline $\begin{array}{l}\text { Strategic } \\
\text { Goals }\end{array}$ & $\begin{array}{l}\text { Strategic } \\
\text { size }\end{array}$ & $\begin{array}{c}\text { Strategic } \\
\text { target }\end{array}$ & $\begin{array}{c}\text { Actual } \\
\text { conditi } \\
\text { ons }\end{array}$ & $\begin{array}{l}\text { Achiev } \\
\text { ement }\end{array}$ \\
\hline \multirow{3}{*}{$\begin{array}{l}\text { Answering } \\
\text { the } \\
\text { challenges } \\
\text { of the future } \\
\text { by } \\
\text { educating } \\
\text { and training } \\
\text { the IT staff } \\
\text { as well a } \\
\text { research on } \\
\text { the } \\
\text { developmen } \\
\text { t of IT }\end{array}$} & $\begin{array}{l}\text { timely and } \\
\text { accurate } \\
\text { informatio } \\
\text { n. }\end{array}$ & $75 \%$ & $72 \%$ & $74 \%$ \\
\hline & $\begin{array}{l}\text { The } \\
\text { informatio } \\
\mathrm{n} \text { is } \\
\text { presented } \\
\text { in } \\
\text { accordanc } \\
\text { e with the } \\
\text { needs and } \\
\text { activities. }\end{array}$ & $75 \%$ & $73 \%$ & $74 \%$ \\
\hline & $\begin{array}{l}\text { Timely } \\
\text { delivery } \\
\text { of } \\
\text { informatio } \\
\text { n. }\end{array}$ & $75 \%$ & $61 \%$ & $68 \%$ \\
\hline \multicolumn{4}{|l|}{ Total } & $216 \%$ \\
\hline \multicolumn{4}{|l|}{ Average } & $72 \%$ \\
\hline
\end{tabular}

Furthermore, the weighting of the strategic objectives for each perspective of the IT Balanced Scorecard were determined. The weights are set based on observations during the study in PUSTIPANDA which was then approved by the management. Weights are determined to find the results of interest of each outcome measure. The weights are obtained under the agreement and approval of the parties. Furthermore, target fulfilment level results at each IT perspective Balanced Scorecard will be determined (Table 12) as well as the results of performance measurement of academic website.

Table 11. Results of Strategic Objectives Weighting

\begin{tabular}{|c|c|c|c|c|}
\hline $\begin{array}{l}\text { Perspe } \\
\text { ctive }\end{array}$ & Strategic Goals & $\begin{array}{l}\text { Wei } \\
\text { ght }\end{array}$ & $\begin{array}{l}\text { Resu } \\
\text { lt } \\
\text { Size }\end{array}$ & $\begin{array}{l}\text { Resu } \\
\text { lts } \\
\text { Goal } \\
\text { s } \\
\end{array}$ \\
\hline $\begin{array}{l}\text { User } \\
\text { Orienta } \\
\text { tion }\end{array}$ & $\begin{array}{l}\text { Answering the } \\
\text { challenges of the future } \\
\text { by educating and } \\
\text { training the IT staff as } \\
\text { well a research on the } \\
\text { development of IT }\end{array}$ & $50 \%$ & $73 \%$ & $\begin{array}{l}54.7 \\
5 \%\end{array}$ \\
\hline $\begin{array}{l}\text { Contri } \\
\text { butions } \\
\text { Organi } \\
\text { zation }\end{array}$ & $\begin{array}{l}\text { Providing maximum IT } \\
\text { products and services for } \\
\text { effective and efficient } \\
\text { information systems }\end{array}$ & $55 \%$ & $73 \%$ & $\begin{array}{l}58.4 \\
\%\end{array}$ \\
\hline $\begin{array}{l}\text { Operati } \\
\text { onal } \\
\text { excelle } \\
\text { nce }\end{array}$ & $\begin{array}{l}\text { Achieve organizational } \\
\text { contribution that is the } \\
\text { business value of } \\
\text { information technology } \\
\text { and the effectiveness } \\
\text { from the application } \\
\text { information system }\end{array}$ & $53 \%$ & $73 \%$ & $\begin{array}{l}56.9 \\
4 \%\end{array}$ \\
\hline $\begin{array}{l}\text { Future } \\
\text { Orienta } \\
\text { tion }\end{array}$ & $\begin{array}{l}\text { Providing information } \\
\text { systems on-demand to } \\
\text { achieve user satisfaction }\end{array}$ & $50 \%$ & $72 \%$ & $54 \%$ \\
\hline
\end{tabular}

Table 12. Results of Measurement

\begin{tabular}{|l|l|}
\hline Perspective & Results Goals \\
\hline User Orientation & $54.75 \%$ \\
\hline Contributions Organization & $58.4 \%$ \\
\hline Operational Improvement & $56.94 \%$ \\
\hline Future Orientation & $54 \%$ \\
\hline Total & $224.09 \%$ \\
\hline Average & $56.02 \%$ \\
\hline
\end{tabular}

\section{Analysis of Data}

The results of data processing of 15 respondents in the four perspectives of the IT balanced scored card showed that on user orientation, the contribution of organizational and operational excellence have $73 \%$ which is in the position of 'Very Good'. However to the perspective of the future orientation, the value is $72 \%$ so it is in a position "Good". In addition, when viewed from the weighting of the strategic objectives, the four perspectives has a score of $54-58 \%$ so that only occupy the position of "Good enough". The position is obtained from the value of final performance on the method of Balanced Scored Card

\section{CONCLUSIONS}

The measurement results was obtained from the four IT balanced scored card perspectives on the AIS UIN Jakarta academic web. The perspective of User Orientation gets $54.75 \%$, Organizational Contributions get $58.4 \%$, Operational Perfection gets $56.94 \%$ and Future Orientation gets $54 \%$ with each category at "Good" level

The perspective results from the four perspectives of the IT Balanced Score Card for academic web in average is $56.02 \%$ where the score is at the level of "Good enough".

\section{REFERENCES}

[1 Diao Zhe, Wang Qinghong, Su Naizheng, Zhang Yuhan, "Study on Data Security Policy Based on Cloud Storage", IEEE International Conference on Big Data Security on Cloud, pp. 145-149, 2017

[2] S. H. L. Kanickam, L. Jayasimman and A. N. Jebaseeli, "A Survey on Layer Wise Issues and Challenges in Cloud Security," 2017 World Congress on Computing and Communication Technologies (WCCCT), Tiruchirappalli, 2017, pp. 168-171.

[3] W. Su, W. Liu, C. Chen and T. Chen, "Cloud access control in multi-layer cloud networks," 2015 IEEE International Conference on Consumer Electronics - Taiwan, Taipei, 2015, pp. 364-365.

[4] Munjal, Meenaakshi. Cloud Storage in Education. International Journal of Computer Science and Management Research. 3.2014. 3818-3823.

[5] Goyal, Nitika \& Goyal, Deepam. Cloud Computing in Educational Research.International Journal of Recent Engineering Research and Development. 2016. 1. 1-5..

[6] Lizhong Tong, Rong Xiao and Huajie Li, "The evaluation of lean logistics performance based on balanced score card and unascertained sets," 2015 International Conference on Logistics, Informatics and Service Sciences (LISS), Barcelona, 2015, pp. 1-7.

[7] H. Kazemkhanlou and H. Ahadi, "An integrated approach using data envelopment analysis and balanced score card to supply chain performance evaluation," 2015 International Conference on Industrial Engineering and Operations Management (IEOM), Dubai, 2015, pp. 1-8. 
13] M. L. Pandini, Z. Arifin and D. M. Khairina, "Design web service academic information system based multiplatform," 2014 The 1st International Conference on Information Technology, Computer, and Electrical Engineering, Semarang, 2014, pp. 297-302.

[14] R. Somya, D. Manongga and M. A. Ineke Pakereng, "ServiceOriented Business Intelligence (SoBI) for Academic and Financial Data Integration in University," 2018 International Seminar on Application for Technology of Information and Communication, Semarang, 2018, pp. 1-5..

[15] H. Hajjar and A. Hajjar, "Software for Academic Registration for IUT SAIDA: Web-Based Online Academic Registration and Management," 2016 International Conference on Computational Science and Computational Intelligence (CSCI), Las Vegas, NV, 2016, pp. 338-343.

[16] Y. M. Solomentsev et al., "Research of the academic web space in the Russian federation," 2016 IEEE Conference on Quality Management, Transport and Information Security, Information Technologies (IT\&MQ\&IS), Nalchik, 2016, pp. 221-223.

2] Gürel, Emet. SWOT ANALYSIS: A THEORETICAL REVIEW. Journal of International Social Research. 2017. 10. 994-1006. 10.17719/jisr.2017.1832.. 